ISSN: 2302-8556

E-Jurnal Akuntansi Universitas Udayana

Vol.26.2.Februari (2019): 1518-1544

DOI: https://doi.org/10.24843/EJA.2019.v26.i02.p25

\title{
Faktor - Faktor Yang Mempengaruhi Nilai Perusahaan Melalui Corporate Social Responsibility (CSR)
}

\author{
Mardi $^{1}$ \\ Hermanto $^{2}$ \\ Erna Widiastuty ${ }^{3}$ \\ ${ }^{1,2,3}$ Fakultas Ekonomi dan Bisnis Universitas Mataram (Unram), NTB, Indonesia \\ e-mail : mardisambelia@gmail.com
}

\begin{abstract}
ABSTRAK
Tujuan jangka pendek perusahaan untuk memaksimalkan laba dan tujuan jangka panjang untuk meningkatkan nilai perusahaan. Tujuan dari penelitian ini untuk mengetahui pengaruh ukuran perusahaan, dewan komisaris, perencanaan bonus, dan kinerja keuangan pada nilai perusahaan melalui pengungkapan CSR. Populasi penelitian sebanyak 172 perusahaan dengan jumlah sampel sebanyak 113 perusahaan. Teknik analisis data menggunakan analisis jalur. Hasil statistik menunjukkan ukuran perusahaan tidak berpengaruh terhadap pengungkapan CSR maupun nilai perusahaan, perencanaan bonus tidak berpengaruh terhadap pengungkapan CSR namun berpengaruh terhadap nilai perusahaan, sedangkan dewan komisaris dan kinerja keuangan berpengaruh terhadap pengungkapan CSR maupun nilai perusahaan, sementara pengungkapan CSR berpengaruh terhadap nilai perusahaan tetapi belum mampu menjadi variabel intervening.

Kata kunci: Ukuran perusahaan; dewan komisaris; perencanaan bonus; kinerja keuangan; CSR; nilai perusahaan
\end{abstract}

\begin{abstract}
ABSTRAC
The company's short-term goals to maximize profits and long-term goals to increase company value. The purpose of this study is to determine the effect of company size, board of commissioners, bonus planning, and financial performance on firm value through CSR disclosure. The study population was 172 companies with a total sample of 113 companies. The data analysis technique uses path analysis. Statistical results show that firm size does not affect CSR disclosure or company value, bonus planning does not affect CSR disclosure but affects company value, while board of commissioners and financial performance influence CSR disclosure and company value, while CSR disclosure has an effect on firm value but not yet able to become an intervening variable.

Keywords: Firm sizes; board of commissioners; bonus planning; financial performance; CSR; firm value
\end{abstract}

\section{PENDAHULUAN}

Perusahaan sebagai suatu entitas ekonomi umumnya memiliki tujuan jangka pendek maupun tujuan jangka panjang. Tujuan jangka pendek perusahaan adalah untuk memperoleh laba secara maksimal, sedangkan tujuan jangka panjangnya adalah untuk meningkatkan nilai perusahaan. Peningkatan nilai perusahaan 
Mardi, Hermanto dan Erna Widiastuty. Faktor...

merupakan hal yang sangat penting bagi perusahaan, karena nilai perusahaan merupakan cerminan dari baik buruknya kinerja perusahaan yang tentu saja akan mempengaruhi pandangan investor pada perusahaan (Kusumayanti dan Astika, 2016). Nilai perusahaan merupakan harga jual perusahaan yang dianggap layak oleh calon investor sehingga ia mau membayarnya jika perusahaan akan dijual. Calon investor akan rela mengorbankan dana yang dimiliki untuk dapat membeli dan memiliki perusahaan yang dapat memberi keuntungan yang besar di masa akan dating. Bagi pihak kreditor, nilai perusahaan berkaitan dengan likuiditas perusahaan yaitu perusahaan dikatakan mampu atau tidaknya membayar atau mengembalikan pinjaman yang diberikan oleh pihak kreditor. Perusahaan yang memiliki nilai perusahaan yang baik dikatakan mampu mengembalikan dana yang dipinjamkan oleh kreditor (Junizar, 2015).

Faktor-faktor yang mempengaruhi nilai perusahaan dapat dibedakan antara faktor financial (keuangan) dan faktor non-financial (bukan keuangan). Faktor financial (keuangan) seperti kinerja keuangan, peningkatan atau penurunan laba, kualitas laba, ukuran perusahaan dan pengambilan keputusan keuangan oleh pihak manajemen perusahaan. Umumnya, faktor keuangan merupakan faktor yang paling sering digunakan untuk menjelaskan mengenai bagaimana pengaruhnya pada nilai perusahaan. Sementara faktor non-financial yang dapat mempengaruhi nilai perusahaan salah satunya adalah pertangungjawaban sosial perusahaan atau Corporate Social Responsibility (CSR) dan ukuran dewan komisaris (Kusumayanti dan Astika, 2016). Secara teoritis Corporte Social Responsibility (CSR) merupakan inti dari etika bisnis, dimana suatu perusahaan tidak hanya 
mempunyai kewajiban-kewajiban ekonomis dan legal kepada pemegang saham (Shareholders) tetapi perusahaan juga mempunyai kewajiban terhadap pihak lain yang berkepentingan (Stakeholders) dan tidak dapat lepas dari kenyataan bahwa suatu perusahaan tidak bisa hidup, beroperasi, bertahan dan memperoleh keuntungan tanpa bantuan dari berbagai pihak. Dengan demikian, CSR lebih menunjukkan kepedulian perusahaan terhadap kepentingan pihak-pihak lain secara lebih luas (Stakeholders) daripada hanya sekedar kepentingan perusahaan itu sendiri (Putri dan Christiawan, 2014). Dikeluarkannya peraturan-peraturan yang mengatur tentang pengungkapan CSR seperti dalam Undang-Undang perseroan terbatas No. 40 pasal 74 Tahun 2007 dan Undang-Undang No. 25 Tahun 2007 tentang penanaman modal tersebut membuat semakin banyak perusahaan dalam beberapa tahun terakhir ini yang mulai menyadari pentingnya penerapan CSR sebagai salah satu bentuk investasi yang baik demi pertumbuhan dan keberlanjutan bisnis perusahaan, yang tentunya akan berdampak pada peningkatan nilai perusahaan. CSR kini juga dipandang sebagai parameter dalam melaksanakan praktik bisnis yang ideal (Kusumayanti dan Astika, 2016).

Ada beberapa faktor yang mempengaruhi praktik pengungkapan CSR. Hal ini merupakan konsekuensi logis dari implementasi konsep good corporate governance (GCG) yang memiliki prinsip antara lain yaitu perusahaan perlu memperhatikan kepentingan stakeholders sesuai dengan aturan yang ada dan menjalin kerjasama yang aktif dengan stakeholders demi kelangsungan hidup jangka panjang perusahaan. Berbagai kegiatan CSR pada perusahaan umumnya berdampak pada pengeluaran, yang pada akhirnya akan mengurangi keuntungan 
perusahaan. Hal tersebut merupakan salah satu tujuan perusahaan untuk memaksimalkan kekayaan pemegang saham yang dioperasionalkan dengan memaksimumkan keuntungan. Hal ini menyebabkan kegiatan CSR sepertinya tidak konsisten dengan tujuan tersebut. Dengan demikian, perusahaan tidak termotivasi untuk melaksanakan CSR (Putri dan Christiawan, 2014).

Pada laporan tahunannya, perusahaan telah menyebutkan aspek pertangungjawaban sosial walaupun dalam bentuk yang relatif sederhana. Perusahaan berhak memilih bentuk pengungkapan yang sesuai dengan kebutuhan dan kompleksitas organisasinya. Meskipun informasi mengenai CSR yang diungkap dalam laporan tahunan tersebut belum mendetail, itikad baik perusahaan ini perlu untuk mendapatkan apresiasi. Setidaknya perusahaan telah menyadari pentingnya informasi yang terkait dengan CSR. Namun trend untuk saat ini, banyak pelaporan CSR dikalangan perusahaan-perusahaan go-public digunakan untuk mengambil sisi positif dari pelaporan CSR tersebut. Saat profitabilitas perusahaan tinggi, maka pihak manajemen akan berasumsi bahwa menginformasikan hal-hal yang dapat mengganggu kesuksesan keuangan perusahaan tersebut tidak perlu dilakukan. Namun, saat perusahaan memiliki tingkat profitability yang rendah, maka perusahaan berharap para pengguna laporan akan membaca "good news" dari kinerja sosial dan lingkungan yang telah dilakukan oleh perusahaan (Sembiring, 2005 dalam Sriayu dan Mimba, 2013).

Kinerja keuangan seperti profitabilitas merupakan salah satu faktor yang mampu mempengaruhi tingkat pengungkapan CSR dan tentunya dapat berpengaruh pada tinggi rendahnya nilai suatu perusahaan. Menurut 
Pustikaningsih (2011), CSR berhubungan dengan kinerja keuangan dengan probabilitas $1 \%$, terdapat hubungan yang positif antara karakteristik CSR dengan karakteristik kinerja kauangan. Hal yang sama juga dengan hasil penelitian Indraswari dan Astika (2015), bahwa profitabilitas yang diproksikan dengan Return On Assets (ROA) berpengaruh positif pada pengungkapan corporate social responsibility di Bursa Efek Indonesia periode 2010-2012. Sementara hasil penelitian Yuliana dkk., (2008) menyatakan bahwa profitabilitas yang diproksikan dengan ROA dan Return On Equity (ROE) tidak terbukti berpengaruh terhadap tingkat keluasan pengungkapan CSR.

Ukuran perusahaan diperkirakan dapat mempengaruhi tingkat pengungkapan CSR. Menurut Sembiring dalam Wijaya (2012), semakin besar suatu perusahaan maka biaya keagenan yang muncul juga semakinbesar. Perusahaan yang besar cenderung mengungkapkan informasi sosial secara lebih luas. Pengaruh ukuranperusahaan terhadap pengungkapan tanggung jawab sosial tercermin dalam teori agensi yang menjelaskan bahwaperusahaan besar mempunyai biaya agensi yang besar, hal tersebut menyebabkan perusahaan besar akan lebih banyakmengungkapkan semua informasi daripada perusahaan kecil. Hasil penelitian Wijaya (2012), bahwa ukuran perusahaan memiliki pengaruh positif signifikan terhadap pengungkapan tanggung jawab sosial. Menurutnya, Positif mengandung arti semakin besar perusahaan akan melakukan pengungkapan tanggung jawab sosial yang lebih luas. Hasil penelitian yang sama oleh (Purwanto, 2011; Dewi dan Priyadi, 2013; Sriayu dan Mimba, 2013; Alkababji, 2014; Indraswari dan Astika, 2015), menemukan bahwa ukuran 
perusahaan berpengaruh positif dan signifikan terhadap tingkat pengungkapan CSR. Namun ada juga hasil penelitian yang menemukan bukti bahwa ukuran perusahaan tidak berpengaruh signifikan terhadap tingkat pengungkapan CSR (Yuliana dkk., 2008; Oktariani dan Mimba, 2014).

Dewan komisaris independen memainkanperan penting dalam meningkatkan image perusahaan. Oleh karena itu, dewan komisaris independen dapat mendorong perusahaan untuk mengungkapakan informasi sosial dan lingkungannya karena hal tersebut dapat meningkatkan image perusahaan di mata masyarakat (Webb, 2004 dalam Oktariani dan Mimba, 2014). Oleh karena itu, ukuran dewan komisaris termasuk faktor yang mempengaruhi tingkat pengungkapan CSR. Penelitian Setyarini dan Paramitha (2011), menemukan hasil bahwa jumlah dewan komisaris independen berpengaruh terhadap tingkat pengungkapan pertanggungjawaban sosial perusahaan atau CSR dengan nilai Signifikan. Penelitian Badjuri (2011), Dewi dan Priyadi (2013), mendukung hasil penelitian tersebut bahwa secara parsial dan simultan ukuran dewan komisaris terbukti berpengaruh terhadap tingkat pengungkapan CSR pada laporan tahunan perusahaan manufaktur. Namun hasil yang berbeda dari penelitian Oktariani dan Mimba (2014), bahwa ukuran dewan komisaris tidak berpengaruh signifikan pada tingkat pengungkapan CSR perusahaan pertambangan yang terdaftar di Bursa Efek Indonesia periode 2008-2012. Hasil tersebut juga sejalan dengan penelitian Wijaya (2012), Sriayu dan Mimba (2013).

Positive Accounting Theory (PAT) berhubungan dengan karakteristik rencana bonus perusahaan dan ukuran perusahaan secara positif terkait dengan 
pengungkapan sosial dan lingkungan perusahaan sementara antara leverage dan tingkat pengungkapan sosial dan lingkungan berhubungan negatif dengan pengungkapan sosial dan lingkungan perusahaan (Setyorini dan Ishak, 2012). CSR dan manajemen laba berhubungan negatif dalam industri minyak dan gas, tetapi berhubungan positif dalam industri makanan. Temuan ini menunjukkan hubungan yang saling melengkapi antara kualitas laba dan Pengungkapan CSR (Yip dkk., 2011). Terdapat hubungan yang positif dan signifikan antara tingkat pengungkapan CSR dan ukuran perusahaan, dan tidak ada korelasi antara tingkat pengungkapan CSR dengan Profitabilitas (Alkababji, 2014).

Dalam beberapa penelitian, CSR disebut berpengaruh langsung untuk meningkatkan nilai perusahaan. Junizar (2015) menemukan bahwa CSR berpengaruh positif terhadap nilai perusahaan manufaktur. Hasil tersebut sejalan dengan penelitian Sindhudipta dan Yasa (2013), Adnantara (2013), dan rahmazaniati dkk.,(2014) juga menemukan bahwa CSR berpengaruh signifikan terhadap nilai perusahaan. Baik secara langsung, CSR juga berpengaruh secara tidak langsung atau sebagai perantara (intervening) untuk meningkatkan nilai suatu perusahaan. Adnantara (2013), menyatakan bahwa secara langsung tidak ada struktur kepemilikansaham yang berpengaruh signifikan terhadap nilai perusahaan. Namun secara tidak langsung, CSR mampu memediasi hubungan antara struktur Kepemilikan Institusional dan Kepemilikan Publik terhadap Nilai Perusahaan. Rahmazaniati dkk., (2014) juga menyatakan bahwa terdapat pengaruh mediasi secara parsial (partial mediation) padamodel penelitiannya, yaitu pengaruh profitabilitas dan financial leverage terhadap nilai perusahaan melalui 
pengungkapan CSR secara parsial (partial mediation). Namun hasil berbeda dari Kusumayanti dan Astika (2016), bahwa CSR tidak mampu menjadi variabel intervening hubungan antara ukuran perusahaan, profitabilitas dan leverage dengan nilai perusahaan. Ini berarti ukuran perusahaan, profitabilitas dan leverage tidak mampu memengaruhi nilai perusahaan dengan adanya pelaksanaan CSR oleh perusahaan. Begitu juga penelitian Bilayudha dan Kiswanto (2015), bahwa CSR tidak mampu memediasi pengaruh kepemilikan institusional, kepemilikan publik, dan komite audit terhadap nilai perusahaan.

Mengacu pada uraian diatas, bahwa terdapat hasil penelitian yang beragam. Dalam penelitian ini, peneliti tertarik untuk meneliti kembali CSR dan nilai perusahaan. Oleh karena itu penelitian ini akan meneliti pengaruh ukuran perusahaan, ukuran dewan komisaris, perencanaan bonus, dan kinerja keuangan terhadap nilai perusahaan dengan tingkat pengungkapan corporate social responsibility (CSR) sebagai variabel mediasi.

\section{METODE PENELITIAN}

Perumusan hipotesis berdasakan rancangan penelitian yang dibuat dengan mengacu pada konsep teori yang digunakan dan didukung dengan penelitian terdahulu. Variabel ukuran perusahaan, dewan komisaris, perencanaan bonus, dan kinerja keuangan diperkirakan memiliki pengaruh terhadap nilai perusahaan baik secara langsung maupun tidak langsung melalui pengungkapan corporate social responsibility. Rancangan penelitian yang dibuat sebagai berikut: 


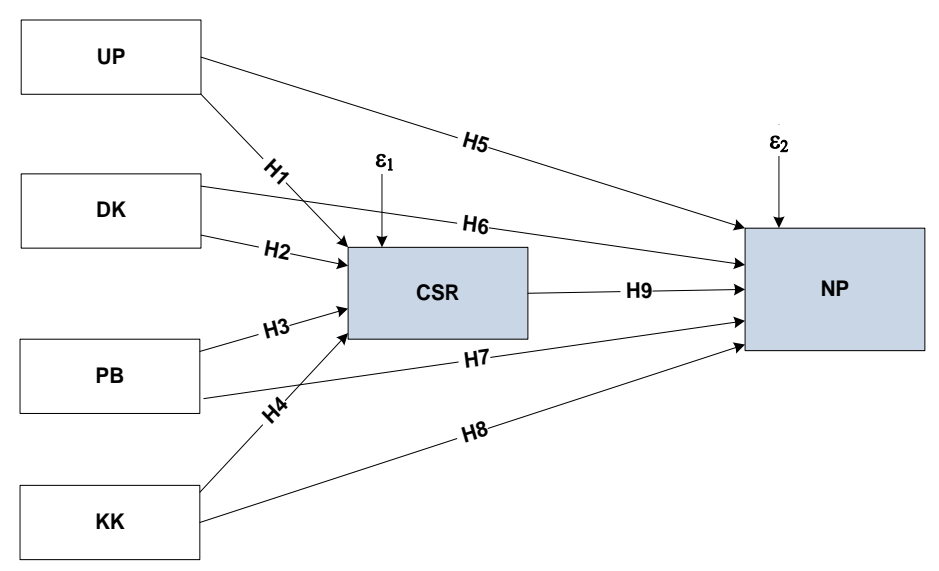

Gambar 1. Rancangan penelitian

Sumber: Kerangka Berpikir Penelitian, 2015

Dari rancangan penelitian tersebut dapat dirumuskan hipotesis penelitian sebagai berikut:

$\mathrm{H}_{1}$ : Ukuran perusahaan berpengaruh terhadap Pengungkapan CSR

$\mathrm{H}_{2}$ : Ukuran dewan komisaris berpengaruh terhadap Pengungkapan CSR

$\mathrm{H}_{3}$ : Perencanaan bonus berpengaruh terhadap Pengungkapan CSR

$\mathrm{H}_{4}$ : Kinerja keuangan berpengaruh terhadap Pengungkapan CSR

$\mathrm{H}_{5}$ : Ukuran perusahaan berpengaruh terhadap Nilai Perusahaan

$\mathrm{H}_{6}$ : Ukuran Dewan Komisaris berpengaruh terhadap Nilai Perusahaan

$\mathrm{H}_{7}$ : Perencanaan Bonus berpengaruh terhadap Nilai Perusahaan

$\mathrm{H}_{8}$ : Kinerja Keuangan berpengaruh terhadap Nilai Perusahaan

$\mathrm{H}_{9}$ : Pengungkapan CSR berpengaruh terhadap Nilai Perusahaan

Ukuran perusahaan merupakan skala dimana perusahaan dapat diklasifikasikan besar, sedang, dan kecil. Pengukuran ukuran perusahaan dengan menggunakan proksi jumlah tenaga kerja dan total aset juga memperlihatkan tingkat produktivitas dan skala ekonomi perusahaan (Yuliana dkk., 2008). 
Penelitian ini menggunakan jumlah tenaga kerja untuk mengukur ukuran perusahaan.

Dewan komisaris berfungsi untuk memonitor dan mengendalikan CEO. Semakin besar jumlah anggota dewan komisaris, maka akan semakin mudah untuk mengendalikan CEO dan monitoring yang dilakukan akan semakin efektif (Yuliana dkk., 2008). Ukuran dewan komisaris diukur menggunakan jumlah dewan komisaris perusahaan.

Perencanaan bonus

Rencana bonus berkaitan dengan besarnya laba suatu perusahaan. Semakin tinggi laba perusahaan maka bonus yang didapatkan oleh komite dewan juga semakin tinggi (Setyorini dan Ishak, 2012). Perencanaan bonus diukur dengan laba perusahaan.

Kinerja keuangan merupakan suatu gambaran tentang kondisi keuangan suatu perusahaan yang dianalisis dengan alat-alat analisis keuangan. Penelitian Pustikaningsih (2011) mengukur kinerja keuangan menggunakan pengukuran Profitabilitas (Profit) dikurangi ROE dan ROS. Penelitian ini menggunakan ROA untuk mengukur kinerja keuangan.

Pengungkapan CSR yaitu tingkat keluasan laporan kegiatan sosial perusahaan dengan tujuan memberikan informasi kepada pengguna laporan keuangan tahunan dan kegiatan sosial yang dilakukan untuk mengurangi dampak negatif yang dialami perusahaan. pengungkapan tanggung jawab sosial perusahaan seperti pada item ekonomi, lingkungan hidup, praktek tenaga kerja, hak asasi manusia, kemasyarakatan dan tanggungjawab produk. Pengukuran 
ISSN: 2302-8556

E-Jurnal Akuntansi Universitas Udayana Vol.26.2.Februari (2019): 1518-1544

tingkat pengungkapan CSR dalam penelitian ini dengan Corporate Social Responsibility Index (CSRI) dengan Rumussebagai berikut:

$\operatorname{CSRI}_{j}=\frac{\Sigma \mathrm{X}_{\mathrm{ij}}}{\mathrm{n}_{\mathrm{j}}}$

Keterangan:

$\mathrm{CSRI}_{\mathrm{j}}=$ Corporate Social Responsibility index perusahaan $\mathrm{j}$

$\mathrm{X}_{\mathrm{ij}}=$ Jumlah skor total pengungkapan item

$\mathrm{n}_{\mathrm{j}}=$ Jumlah total item $(78)$

Nilai perusahaan yang tinggi akan diikuti oleh tingginya kemakmuran pemegang saham. Semakin tinggi harga saham maka semakin tinggi nilai perusahaan (Sindhudiptha dan Yasa, 2013). Digunakan Tobin's Q untuk mengukur nilai perusahaan. Rumus dari Tobin's Q yaitu:

$$
\operatorname{Tobin}^{\prime} \mathrm{S} Q=\frac{M V E+D E B T}{\mathrm{TA}} \text {. }
$$

Keterangan:

MVE = Nilai pasar ekuitas (closing price $\mathrm{x}$ jumlah saham yang beredar)

DEBT = Nilai buku dari total hutang (kewajiban jangka pendek + kewajiban jangka panjang)

TA $=$ Total aktiva

Data yang digunakan merupakan data sekunder yang diambil dari laporan tahunan perusahaan Go public di bursa efek indonesia.Populasi yang digunakan dalam penelitian ini sebanyak 172 perusahaan yang termasuk dalam kategori perusahaan high profile yang terdaftardi Bursa Efek Indonesia periode 2015. Teknik pengambilan sampel dengan metode purposive sampling. Adapun karakteristik sampel penelitian ini disajikan dalam tabel sebagai berikut: 
Tabel 1.

Karakteristik sampel

\begin{tabular}{clc}
\hline No & \multicolumn{1}{c}{ Kriteria } & $\begin{array}{c}\text { Jumlah } \\
\text { Perusahaan }\end{array}$ \\
\hline 1 & $\begin{array}{l}\text { Perusahaan yang termasuk dalam kategori perusahaan high profile } \\
\text { dan terdaftar di BEI per 31 Desember 2015 }\end{array}$ & 172 \\
2 & $\begin{array}{l}\text { Perusahaan yang tidak menyajikan laporan keuangan tahunan dengan } \\
\text { lengkap per 31 }\end{array}$ & (54) \\
& $\begin{array}{l}\text { Desember 2015 } \\
\text { Perusahaan yang tidak menyajikan pengungkapan CSR dalam } \\
\text { laporan tahunannya per 31 Desember 2015 } \\
\quad \text { Total sampel }\end{array}$ & (5) \\
\hline Sumber: Data diolah, 2015 & 113 \\
\hline
\end{tabular}

Penelitian ini bertujuan untuk menganalisis ukuran perusahaan (UP), ukuran dewan komisaris (DK), perencanaan bonus (PB), dan kinerja keuangan (KK) terhadap nilai perusahaan (NP) baik secara langsung maupun melalui pengungkapan corporate social responsibility (CSR). Pengujian dilakukan dengan menggunakan analisis jalur dengan dua model persamaan yaitu:

$\mathrm{CSR}=\alpha_{1} \mathrm{UP}+\alpha_{2} \mathrm{DK}+\alpha_{3} \mathrm{~PB}+\alpha_{4} \mathrm{KK}+\mathrm{x}_{1} \varepsilon_{1}$

$\mathrm{NP}=\beta_{1} \mathrm{UP}+\beta_{2} \mathrm{DK}+\beta_{3} \mathrm{~PB}+\beta_{4} \mathrm{KK}+Y \mathrm{CSR}+\mathrm{x}_{2} \varepsilon_{2}$

Tabel 2.

Hasil Uji Multikolonieritas

\begin{tabular}{|c|c|c|c|}
\hline & \multirow{2}{*}{ Model } & \multicolumn{2}{|c|}{ Collinearity Statistics } \\
\hline & & Tolerance & VIF \\
\hline \multirow[t]{6}{*}{1} & (Constant) & & \\
\hline & UP & .498 & 2.010 \\
\hline & DK & .704 & 1.421 \\
\hline & PB & .564 & 1.774 \\
\hline & KK & .858 & 1.165 \\
\hline & CSR & .778 & 1.285 \\
\hline
\end{tabular}

a. Dependent Variable: NP

Sumber: Data Diolah, 2015

Nilai tolerance terkecil sebesar 0.498. artinya tidak ada variabel independen yang memiliki nilai tolerance lebih kecil dari 0,10 . Berarti tidak terjadi multikolonieritas antar variabel independen. 
Tabel 3.

Hasil Uji Normalitas

One-Sample Kolmogorov-Smirnov Test

\begin{tabular}{|c|c|c|}
\hline \multirow[b]{2}{*}{$\mathrm{N}$} & & Unstandardized Residual \\
\hline & & 113 \\
\hline \multirow[t]{2}{*}{ Normal Parameters $^{a}$} & Mean & .0000000 \\
\hline & Std. Deviation & 1.66111299 \\
\hline \multirow[t]{3}{*}{ Most Extreme Differences } & Absolute & .059 \\
\hline & Positive & .039 \\
\hline & Negative & -.059 \\
\hline Kolmogorov-Smirnov $Z$ & & .625 \\
\hline Asymp. Sig. (2-tailed) & & .830 \\
\hline
\end{tabular}

Nilai Kolmogorov-Smirnov sebesar 0.625 dan tingkat probabilitas signifikansi diatas 0.05 yaitu sebesar 0.830 . hal ini mengindikasikan bahwa data residual terdistribusi secara normal.

Tabel 4.

\section{Hasil Uji Koefisien Determinasi}

Model Summary

\begin{tabular}{llrrr}
\hline Model & $\boldsymbol{R}$ & $\boldsymbol{R}$ Square & Adjusted $\boldsymbol{R}$ Square & Std. Error of the Estimate \\
\hline 1 & $.461^{\mathrm{a}}$ & .463 & .438 & .86522 \\
\hline a. Predictors: (Constant), KK, UP, DK, PB & & \\
Sumber: Data diolah, 2015 &
\end{tabular}

Besarnya nilai Adjusted R Square sebesar 0,438. Nilai ini menerangkan besarnya kontribusi variabel independen yang mampu menjelaskan pengungkapan CSR hanya sebesar $43,8 \%$ sedangkan $56,2 \%$ dijelaskan oleh variabel diluar model.

Tabel 5.

Hasil Uji F Sub-Struktur 1

\begin{tabular}{ccccc}
\hline Model & $\begin{array}{c}\text { Sum of } \\
\text { Squarnes }\end{array}$ & df & F & Sig. \\
\hline 1 Regression & 21.840 & 4 & 7.294 & $.000^{\mathrm{a}}$ \\
Residual & 80.850 & 108 & & \\
Total & 102.690 & 112 & &
\end{tabular}


Diperoleh nilai $\mathrm{F}$ hitung sebesar 7,294 dan signifikan pada 0,000. Karena probabilitas jauh lebih kecil dari 0,05 maka model regresi dapat digunakan untuk memprediksi variabel dependen secara simultan.

Tabel 6.

Hasil Uji t Sub-Struktur 1

\begin{tabular}{lllrrr}
\hline \multirow{2}{*}{ Model } & \multicolumn{3}{c}{$\begin{array}{c}\text { Standardized } \\
\text { Coefficients }\end{array}$} & \multirow{2}{*}{ t } & Sig. \\
\cline { 2 - 3 } & \multicolumn{2}{c}{ Beta } & & \\
\hline 1 & (Constant) & & & -12.210 & .000 \\
& UP & .117 & .984 & .327 \\
DK & & .295 & 2.959 & .004 \\
PB & .023 & .199 & .843 \\
KK & & .217 & 2.383 & .019 \\
\hline
\end{tabular}

a. Dependent Variable: CSR

Sumber: Data diolah, 2015

Nilai signifikansi UP sebesar 0,327 (lebih besar dari 0,05) dan nilai koefisien beta sebesar 0,117. Berarti UP tidak berpengaruh terhadap CSR (hipotesis pertama ditolak). Nilai signifikansi DK terhadap CSR sebesar 0,004 (lebih kecil dari 0,05) dan nilai koefisien beta sebesar 0,295 (hipotesis kedua diterima).

Nilai signifikansi PB sebesar 0,843 (lebih besar dari 0,05) dan nilai koefisien beta sebesar 0,023. berarti PB tidak berpengaruh terhadap CSR (hipotesis ketiga ditolak). Nilai signifikansi KK sebesar 0,019 (lebih kecil dari 0,05) artinya KK berpengaruh signifikan terhadap pengungkapan CSR dan nilai koefisien beta sebesar 0,217 (hipotesis keempat diterima). Dapat dibuat persamaan matematis sebagai berikut:

$\mathrm{CSR}=0,117 \mathrm{UP}+0,295 \mathrm{DK}+0,023 \mathrm{~PB}+0,217 \mathrm{KK}+0,562 \varepsilon_{1}$ 
Tabel 7.

Hasil Uji Koefisien Determinasi

Model Summary

\begin{tabular}{llccr}
\hline Model & $R$ & $R$ Square & $\begin{array}{c}\text { Adjusted } R \\
\text { Square }\end{array}$ & $\begin{array}{c}\text { Std. Error of the } \\
\text { Estimate }\end{array}$ \\
\hline 1 & $.852^{\mathrm{a}}$ & .725 & .712 & 3.3011282 \\
\hline
\end{tabular}

Nilai Adjusted R Square sebesar 0,712. Nilai ini menerangkan besarnya kontribusi variabel independen terhadap variabel dependen sebesar 71,2\% sedangkan $28,8 \%$ dijelaskan oleh variabel diluar model.

Tabel 8.

Hasil Uji F

\begin{tabular}{llrrrr}
\hline \multicolumn{1}{l}{ Model } & Sum of Squares & Df & \multicolumn{1}{c}{ F } & Sig. \\
\hline 1 & Regression & 3.077 & 5 & 56.467 & $.000^{\mathrm{a}}$ \\
& Residual & 1.166 & 107 & & \\
Total & 4.243 & 112 & & \\
\hline
\end{tabular}

a. Predictors: (Constant), CSR, KK, DK, PB, UP

b. Dependent Variable: NP

Sumber: Data diolah, 2015

Nilai F hitung sebesar 56.467 dan signifikan pada 0,000. Karena probabilitas jauh lebih kecil dari 0,05, maka model regresi dapat digunakan untuk memprediksi pengaruh variabel independen terhadap variabel dependen secara simultan.

Tabel 9.

Hasil Uji t

\begin{tabular}{ccccc}
\hline Model & $\begin{array}{c}\text { Standardized } \\
\text { Coefficients }\end{array}$ & $\mathrm{T}$ & Sig. \\
\cline { 2 - 3 } & Beta & & & \\
\hline 1 (Constant) & & 11.162 & & .000 \\
UP & -.048 & -.475 & .636 & \\
DK & .363 & 4.302 & .000 & \\
PB & .287 & 3.043 & .003 & \\
KK & .167 & 2.179 & .032 & \\
CSR & .203 & 2.527 & .013 & \\
\hline
\end{tabular}

a. Dependent Variable: NP

Sumber: Data diolah, 2015 
Mardi, Hermanto dan Erna Widiastuty. Faktor...

Nilai signifikansi UP sebesar 0,636 (lebih besar dari 0,05) dengan nilai koefisien beta sebesar $-0,048$ (hipotesis kelima ditolak). Nilai signifikansi DK sebesar 0,000 (lebih kecil dari 0,05) dengan nilai koefisien beta sebesar 0,363 (hipotesis keenam diterima). Nilai signifikansi PB sebesar 0,003 (lebih kecil dari 0,05) dengan nilai koefisien beta sebesar 0,287 (hipotesis ketujuh diterima).Nilai signifikansi KK sebesar 0,032 (lebih kecil dari 0,05) dengan nilai koefisien beta sebesar 0,167 (hipotesis kedelapan diterima). Nilai signifikansi untuk CSR sebesar 0,01 (lebih kecil dari 0,05) dengan nilai koefisien beta sebesar 0,203 (hipotesis kesembilan diterima). Dapat dibuat persamaan matematis sebagai berikut:

$\mathrm{NP}=-0,048 \mathrm{UP}+0,363 \mathrm{DK}+0,287 \mathrm{~PB}+0,167 \mathrm{KK}+0,203 \mathrm{CSR}+0,288 \varepsilon_{2}$

Tabel 10.

Perhitungan Pengaruh Diagram Jalur

\begin{tabular}{lcccc}
\hline \multirow{2}{*}{$\begin{array}{c}\text { Pengaruh } \\
\text { Variabel }\end{array}$} & Langsung & $\begin{array}{c}\text { Tidak Langsung } \\
\text { (Melalui CSR) }\end{array}$ & Total & Keterangan \\
\cline { 2 - 4 } & -0.048 & 0.024 & -0.024 & Tidak signifikan \\
$\mathrm{UP} \rightarrow \mathrm{NP}$ & 0.363 & 0.060 & 0.423 & Signifikan \\
$\mathrm{DK} \rightarrow \mathrm{NP}$ & 0.287 & 0.005 & 0.292 & Signifikan \\
$\mathrm{PB} \rightarrow \mathrm{NP}$ & 0.167 & 0.044 & 0.211 & Signifikan \\
$\mathrm{KK} \rightarrow \mathrm{NP}$ & 0.203 & & 0.203 & Signifikan \\
$\mathrm{CSR} \rightarrow \mathrm{NP}$ & 0.117 & & 0.117 & Tidak signifikan \\
$\mathrm{UP} \rightarrow \mathrm{CSR}$ & 0.295 & & 0.295 & Signifikan \\
$\mathrm{DK} \rightarrow \mathrm{CSR}$ & 0.023 & & 0.023 & Tidak signifikan \\
$\mathrm{PB} \rightarrow \mathrm{CSR}$ & 0.217 & & 0.217 & Signifikan \\
$\mathrm{KK} \rightarrow \mathrm{CSR}$ & & & &
\end{tabular}




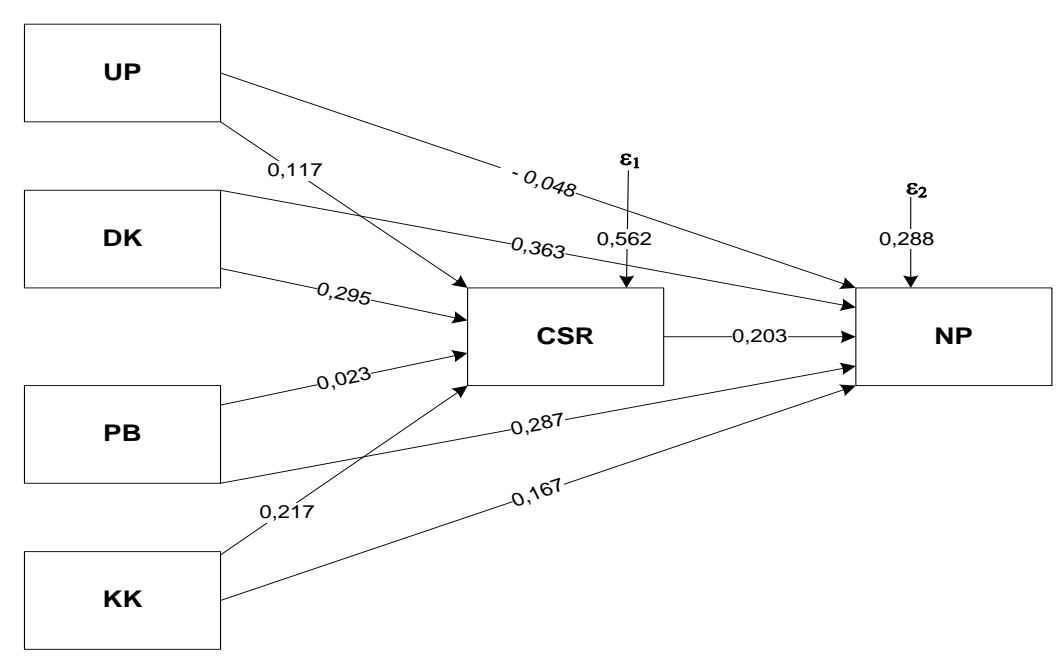

Gambar 2. Diagram koefisien jalur

Sumber: Hasil Uji T Sub-struktur 1 dan 2, 2015

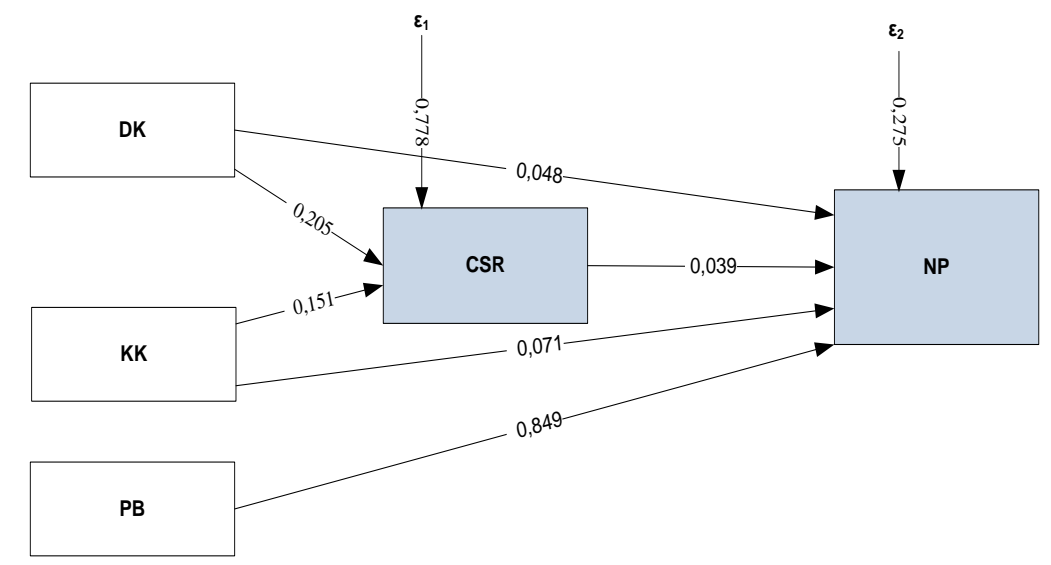

Gambar 3. Diagram jalur model trimming

Sumber: Hasil Uji T Sub-struktur 1 dan 2 yang Signifikan, 2015

\section{HASIL DAN PEMBAHASAN}

Hasil uji hipotesis diperoleh bukti bahwa ukuran perusahaan tidak berpengaruh terhadap tingkat pengungkapan CSR. Hal tersebut karena ketaatan perusahaanperusahaan yang tergolong highprofile dalam menjalankan amanat undang undang No. 40 tahun 2007 tentang perseroan terbatas, dimana salah satu pasalnya mewajibkan perusahaan untuk mengungkapkan aktivitas tanggung jawab sosial dalam laporan tahunan meskipun item-item CSR yang diungkapkan perusahaan 
Mardi, Hermanto dan Erna Widiastuty. Faktor...

merupakan informasi yang masih bersifat sukarela (voluntary). Dengan dikeluarkannya aturan tersebut berarti baik perusahaan ukuran kecil maupun besar wajib melakukan pengungkapan CSR dalam laporan tahunannya. Ketaatan perusahaan dalam melakukan pengungkapan CSR tersebut didukung dengan data statistik bahwa dari 172 perusahaan kategori high profile hanya 5 perusahaan (sekitar 3\%) yang tidak melakukan pengungkapan CSR sedangkan 97\% melakukan pengungkapan dalam laporan tahunan periode 2015. Penerapan program CSR ternyata tidak tergantung pada ukuran perusahaan. Namun lebih tergantung bagaimana cara pandang perusahaan terhadap CSR, apakah hal ini dianggap sebagai hal yang penting atau tidak. Cara pandang ini selanjutnya akan mempengaruhi praktik CSR yang dilakukan oleh perusahaan dan juga akan berdampak pada pengungkapan CSR yang disusunnya. (Pambudi 2006a dalam Yuliana dkk.,2008). Hasil penelitian ini konsisten dengan Oktariani \& Mimba (2014) yang menemukan bahwa ukuran perusahaan tidak berpengaruh terhadap pengungkapan CSR.

Ukuran dewan komisaris berpengaruh signifikan dan sifatnya positif terhadap pengungkapan CSR. Semakin besar dewan komisaris, maka semakin banyak pihak yang melakukan pengawasan terhadap manajemen dalam perusahaan, dengan begitu akan berdampak pada luasnya pengungkapan informasi CSR yang lebih detail dan lengkap. Badjuri (2011) mengatakan dengan meningkatnya fungsi pengawasan dalam memonitoring perusahaan maka dapat meningkatkan pula luas pengungkapan tanggung jawab sosial perusahaan. Dengan demikian jumlah dewan komisaris dapat meningkatkan rating CSR 
(Setyarini \& Paramitha, 2011). Hasil penelitian ini berhasil mendukung teori agensi dan Sembiring (2005) menyatakan bahwa semakin banyak jumlah anggota dewan komisaris dalam suatu perusahaan, maka pengungkapan tanggung jawab sosial yang dibuat perusahaan akan semakin luas (Dewi \& Priyadi, 2013).

Perencanaan bonus tidak berpengaruh terhadap pengungkapan CSR. Perusahaan dalam melaksanakan kegiatan CSR-nya tidak ditentukan oleh tingkat laba yang diperolehnya, melainkan kesadaran dari pihak perusahaan untuk menentukan berapa biaya yang akan dikeluarkan untuk melaksanakan kegiatan CSR. Oleh karena itu, berapa pun laba yang diperoleh oleh suatu perusahaan, hal tersebut tidak akan memengaruhi tingkat pengungkapan CSR yang dilakukan oleh perusahaan tersebut (Kusumayanti \& Astika, 2016).

Kinerja keuangan yang diproksikan dengan ROA berpengaruh signifikan dan mempunyai hubungan positif. Jika perusahaan memiliki tingkat ROA yang tinggi, maka perusahaan akan memiliki dana yang cukup untuk dialokasikan kepada kegiatan sosial dan lingkungan sehingga tingkat pengungkapan pertanggungjawaban sosial oleh perusahaan akan tinggi (Fauzi, et al. 2007 dalam Purwanto, 2011). Hasil penelitian ini konsisten dengan penelitian Indraswari (2015) bahwa ROA memiliki pengaruh yang positif terhadap jumlah pengungkapan CSR yang dilakukan perusahaan terhadap masyarakat. Semakin tinggi tingkat ROA maka semakin besar tingkat pengungkapan CSR yang dilakukan perusahaan.

Ukuran perusahaan tidak berpengaruh terhadap nilai perusahaan. Hal tersebut karena proksi yang digunakan untuk mengukur ukuran perusahaan yaitu faktor 
Mardi, Hermanto dan Erna Widiastuty. Faktor...

non keuangan (jumlah tenaga kerja). Pengukuran ukuran perusahaan dengan menggunakan proksi jumlah tenaga kerja memperlihatkan tingkat produktivitas perusahaan saja dan tidak menggambarkan kemampuan suatu perusahaan dalam meningkatkan harga saham. Berbeda jika ukuran perusahaan diproksikan dengan faktor keuangan seperti total aset. Ukuran perusahaan merupakan salah satu indikasi mengukur kinerja suatu perusahaan. Ukuran perusahaan yang besar dapat mencerminkan jika perusahaan mempunyai komitmen yang tinggi untuk terus memperbaiki kinerjanya, sehingga pasar akan mau membayar lebih mahal untuk mendapatkan sahamnya karena percaya akan mendapatkan pengembalian yang menguntungkan dari perusahaan tersebut. Perusahaan yang besar juga cenderung memiliki kondisi yang lebih stabil, sehingga investor akan tertarik untuk membeli saham perusahaan tersebut, yang berdampak pada peningkatan harga saham perusahaan tersebut di pasar modal (Analisa, 2011 dalam Kusumayanti \& Astika, 2016). Hasil penelitian ini sejalan dengan penelitian Dewi \& Wirajaya (2013) menemukan bahwa ukuran perusahaan tidak berpengaruh pada nilai perusahaan.

Dewan komisaris berpengaruh signifikan dan mempunyai hubungan positif terhadap nilai perusahaan. Artinya peningkatan jumlah dewan komisaris dapat meningkatkan nilai perusahaan. Dewan komisaris berfungsi untuk memonitor dan mengendalikan CEO. Semakin besar jumlah anggota dewan komisaris, maka akan semakin mudah untuk mengendalikan CEO dan monitoring yang dilakukan akan semakin efektif (Sembiring, 2005 dalam Yuliana dkk., 2011). Oleh karena itu, dengan adanya pengendalian dan monitoring yang lebih efektif juga akan menigkatkan kinerja perusahaan dan tentunya akan direspon positif oleh investor 
sehingga besar kemungkinan berdampak terhadap harga saham perusahaan yang lebih tinggi.

Perencanaan bonus yang diproksikan dengan laba perusahaan mempunyai pengaruh yang signifikan dan bersifat positif. Kemampuan perusahaan dalam menghasilkan laba bersih dari aktivitas yang dilakukan pada periode akuntansi akan memberikan indikasi prospek perusahaan yang baik sehingga dapat memicu investor untuk ikut meningkatkan permintaan saham (Prasetyorini, 2013 dalam Rahmazaniati, 2014). Dengan demikian, peningkatan harga saham akan diikuti oleh peningkatan nilai perusahaan. Peningkatan nilai perusahaan akan menimbulkan keyakinan di hati investor untuk berinvestasi pada perusahaan tersebut. Semakin besar laba yang dihasilkan perusahaan, maka akan melahirkan sentimen positif yang sangat kuat kepada para investor, sehingga nilai perusahaan juga akan meningkat dengan relatif besar (Rahmazaniati, 2014).

Kinerja keuangan berpengaruh signifikan positif terhadap nilai perusahaan. Hal ini menunjukkan bahwa semakin baik kinerja keuangan, maka semakin tinggi nilai perusahaan. Perusahaan yang memiliki kinerja yang baik dalam mengelola asetnya mampu menghasilkan profitabilitas tinggi dan akan berpengaruh terhadap nilai perusahaan yang semakin tinggi (Hardiningsih, 2011 dalam Antari \& Dana 2012). Menurut Weston dan Brigham (2001) dalam Nofrita (2013), ROA yang tinggi mencerminkan posisi perusahaan yang bagus sehingga nilai yang diberikan pasar yang tercermin pada harga saham terhadap perusahaan tersebut juga akan bagus. Hasil penelitian ini konsisten dengan penelitian Iriyanti \& Tumbel (2014), 
Mardi, Hermanto dan Erna Widiastuty. Faktor...

Purwaningsih \& Wirajaya (2014) menemukan bahwa kinerja keuangan berpengaruh signifikan terhadap nilai perusahaan.

CSR berpengaruh signifikan dan berhubungan positif pada Nilai Perusahaan. Hal ini sesuai dengan teori stakeholder yang menyatakan perusahaan beroperasi bukan hanyauntuk kepentingan perusahaan itu namun harus memberikan manfaat kepada stakeholder-nya. Apabila perusahaan dapat memaksimalkan manfaat yangditerima stakeholder maka akan timbul kepuasan dan apresiasi bagi stakeholder dan akan meningkatkan nilai perusahaan (Freeman et al., 2006 dalam Rosiana, dkk., 2013). Adnantara (2013) menyatakan bahwa dengan adanya pengungkapan CSR oleh perusahaan, maka investor akan memberikan respon yang positif sehingga banyak investor yang berinvestasi pada perusahaan tersebut dan menyebabkan meningkatnya nilai perusahaan. Hasil penelitian ini sesuai dengan penelitian Sindhudipta \& Yasa (2013), Rahmazaniati (2014), Hermawan \& Maf'ulah (2014) yang menyatakan bahwa corporate social responsibility berpengaruh signifikan terhadap nilai perusahaan.

\section{SIMPULAN}

Berdasarkan hasil pengujian dan analisis data yang dilakukan dapat di peroleh hasil penelitian dan menyimpulkan bahwa Ukuran perusahaan tidak berpengaruh signifikan terhadap pengungkapan CSR maupun nilai perusahaan, Perencanaan bonus tidak berpengaruh signifikan terhadap pengungkapan CSR tetapi berpengaruh signifikan dan berhubungan positif terhadap nilai perusahaan, Dewan komisaris dan kinerja keuangan berpengaruh signifikan dan berhubungan positif terhadap pengungkapan CSR maupun nilai perusahaan, Pengungkapan CSR 
berpengaruh signifikan dan berhubungan positif terhadap nilai perusahaan tetapi tidak bisa menjadi pemediasi antara variabel independen dengan variabel dependen.

Bagi perusahaan yang mengharapkan nilai perusahaan meningkat diharapkan untuk tetap konsisten dalam membuat laporan CSR yang lebih luas dengan memaksimalkan fungsi pengawasan dewan komisaris baik dalam keadaan posisi laba perusahaan meningkat ataupun menurun serta perusahaan dengan skala kecil maupun besar. Karena investor saat ini tidak hanya melihat kesuksesan perusahaan dari segi keuangan saja tetapi faktor non keuangan seperti CSR menjadi daya tarik tersendiri untuk saat ini karena hal tersebut juga bisa menjadi refrensi keberlangsungan perusahaan untuk periode yang akan datang terutama hubungan perusahaan dengan lingkungan dan masyrakat sekitar. Investor tidak hanya melihat skala perusahaan besar maupun kecil untuk mengambil keputusan dalam berinvestasi tetapi lebih menyorot manajemen perusahaan dan seberapa besar jaminan keamanan perusahaan melakukan proses produksi dengan lingkungan sekitar nya.

Bagi peneliti selanjutnya, mengingat implikasi dari kegiatan maupun laporan pengungkapan CSR tidak langsung bisa dirasakan. Untuk itu diharapkan menggunakan periode data dua tahun atau lebih (timeseries) untuk melihat implikasi pengungkapan CSR yang lebih baik dan menganalisis perusahaan yang low profile. Dalam mengukur variabel penelitian, peneliti hanya menggunakan satu indikator tiap variabel, peneliti selanjutnya diharapkan menambah alat ukur 
untuk masing-masing variabel dan menggunakan alat analisis data struktur equation modeling (SEM) sehingga hasil penelitian lebih luas.

\section{REFRENSI}

Adnantara, K. F. (2013). Pengaruh Struktur Kepemilikan Saham dan Corporate Social Responsibility pada Nilai Perusahaan. Buletin Studi Ekonomi.

Alkababji, M. W. (2014). Voluntary disclosure on corporate social responsibility: a study on the annual reports of Palestinian Corporations. European Journal of Accounting Auditing and Finance Research, 2(4), 59-82.

Antari, D. A. P. P., \& Dana, I. M. (2011). Pengaruh Struktur Modal, Kepemilikan Manajerial, Dan Kinerja Keuangan Terhadap Nilai Perusahaan.

Badjuri, A. (2011). Faktor-Faktor Fundamental, Mekanisme Coorporate Governance, Pengungkapan Coorporate Social Responsibility (CSR) Perusahaan Manufaktur dan Sumber Daya Alam di Indonesia. Dinamika Keuangan dan Perbankan, 3(1).

Bilayudha, F., \& Kiswanto, K. (2015). Determinan Nilai Perusahaan Pada Perusahaan Pertambangan Yang Terdaftar di BEI. Accounting Analysis Journal, 4(3).

Crowther, D. (2008). Corporate social responsibility. Bookboon.

Dewi, A. S. M., \& Wirajaya, A. (2013). Pengaruh struktur modal, profitabilitas dan ukuran perusahaan pada nilai perusahaan. E-Jurnal Akuntansi, 358372 .

Dewi, S. S. (2015). Pengaruh Karakteristik Perusahaan Terhadap Corporate Social Responsibilitydisclosure pada Perusahaan Manufaktur yang Terdaftar di BEI. Jurnal Ilmu dan Riset Akuntansi, 2(3).

Ghozali, I. (2006). Aplikasi analisis multivariate dengan program SPSS. Badan Penerbit Universitas Diponegoro.

Hermawan, S., \& Maf'ulah, A. N. (2014). Pengaruh Kinerja Keuangan Terhadap Nilai Perusahaan Dengan Pengungkapan Corporate Social Responsibility Sebagai Variabel Pemoderasi. Jurnal Dinamika Akuntansi, 6(2). 
Indraswari, G. A. D., \& Astika, I. B. P. (2015). Pengaruh profitabilitas, ukuran perusahaan, dan kepemilikan saham publik terhadap pengungkapan csr. E-Jurnal Akuntansi Universitas Udayana, 11(1), 289-302.

Irayanti, D., \& Tumbel, A. L. (2014). Analisis kinerja keuangan pengaruhnya terhadap nilai perusahaan pada industri makanan dan minuman di BEI. Jurnal EMBA: Jurnal Riset Ekonomi, Manajemen, Bisnis dan Akuntansi, 2(3).

Junizar. (2015). Pengaruh Corporate Governance Terhadap Hubungan Corporate Social Responsibility dengan Nilai Perusahaan (Studi Pada Perusahaan Manufaktur yang Terdaftar di Bursa Efek Indonesia). Jurnal Magister Akuntansi Pascasarjana Universitas Syiah KualaBanda Aceh, Indonesia.

Kusumayanti, N. K. R., \& Astika, I. B. P. (2016). Corporate Social Responsibility Sebagai Pemediasi Pengaruh Ukuran Perusahaan, Profitabilitas Dan Leverage Pada Nilai Perusahaan. E-Jurnal Akuntansi, 549-583.

Nofrita, R. (2013). Pengaruh Profitabilitas terhadap Nilai Perusahaan dengan Kebijakan Deviden sebagai Variabel Intervening (Studi Empiris pada Perusahaan Manufaktur yang Terdaftar di BEI). Jurnal Akuntansi, 1(1).

Oktariani, N. W., \& Mimba, N. P. S. H. (2014). Pengaruh Karakteristik Perusahaan dan Tanggung Jawab Lingkungan pada Pengungkapan Tanggung Jawab Sosial Perusahaan. E-Jurnal Akuntansi, 402-418.

Purwaningsih, N. K. I., \& Wirajaya, I. G. A. (2014). Pengaruh Kinerja Pada Nilai Perusahaan Dengan Corporate Social Responsibilty Sebagai Variabel Pemoderasi. E-Jurnal. Universitas Udayana, 7(2014), 598-613.

Purwanto, A. (2011). Pengaruh tipe industri, ukuran perusahaan, profitabilitas, terhadap corporate social responsibility. Jurnal Akuntansi dan Auditing, 8(1), 12-29.

Pustikaningsih, A. (2011). Analisis Hubungan Corporate Social Responsibility (CSR) Terhadap Kinerja Keuangan Pada Perusahaan Jasa (Studi Kasus Perusahaan Jasa di DI Yogyakarta). Jurnal Pendidikan Akuntansi Indonesia, 9 (2).

Putri, R. A. (2014). Pengaruh Profitabilitas, Likuiditas, dan Leverage Terhadap Pengungkapan CSR. Business Accounting Review, 2(1), 61-70.

Rahmazaniati, L., \& Nadirsyah, S. A. (2014). Pengaruh Profitabilitas Dan Financial Leverage Terhadap Pengungkapan Corporate Social Responsibility Serta Dampaknya Terhadap Nilai Perusahaan Pada Perusahaan Yang Termasuk Dalam Indeks Sri-Kehati Yang Terdaftar di 
Bursa Efek Indonesia. Jurnal Administrasi Akuntansi: Program Pascasarjana Unsyiah, 3 (4).

Ratih, Suklimah. (2011). Pengaruh Good Corporate Governance Terhadap Nilai Perusahaan Dengan Kinerja Keuangan Sebagai Variabel Intervening pada Perusahaan Peraih The Indonesia Most Trusted Company-CGPI. Jurnal Kewirausahaan Volume 5 Nomor 2, Desember 2011.

Riduwan, K. E. A., \& Achmad, E. (2007). Cara menggunakan dan memaknai analisis jalur (path analysis). Penerbit: Alfabeta. Bandung.

Sarwono, J. (2007). Analisis jalur untuk riset bisnis dengan SPSS. Penerbit Andi, Yogyakarta, 321.

Rosiana, G. A. M. E. (2013). Gede Juliarsa dan Maria M. Ratna Sari.(2013). Pengaruh Pengungkapan CSR Terhadap Nilai Perusahaan Dengan Profitabilitas Sebagai Variabel Pemoderasi. E-Jurnal Akuntansi Universitas Udayana, 5, 723-738.

Setyarini, Y., \& Paramitha, M. (2011). Pengaruh Mekanisme Good Corporate Governance terhadap Corporate Social Responsibility. jurnal kewirausahaan, 5(2), 10-17.

Setyorini, C. T., \& Ishak, Z. (2012). Corporate social and environmental disclosure: A positive accounting theory view point. International Journal of Business and Social Science, 3(9).

Sindhudiptha, I. N. S. Y., \& Yasa, G. W. (2013). Pengaruh Corporate Social Responsibility pada kinerja keuangan perusahaan dan Implikasinya terhadap nilai perusahaan. E-Jurnal Akuntansi, 388-405.

Sriayu, G. A. P. W., \& Mimba, N. P. S. H. (2013). Pengaruh Karakteristik Perusahaan Terhadap Corporate Social Responsibility Disclosure. EJurnal Akuntansi, 326-344.

Sugiyono. (2006). Metode Penelitian Bisnis. Bandung: CV. Alfabeta

Sugiyono. (2006). Metode Penelitian Kuantitatif Kualitatif dan R\&D. Bandung: CV. Alfabeta.

Sugiyono. (2006). Metode Penelitian Pendidikan, Pendekatan Kuantitatif, Kualitatif dan R\&D. Bandung: Penerbit Alfabeta.

Wijaya, M. (2012). Faktor-faktor yang mempengaruhi pengungkapan tanggung jawab sosial pada perusahaan manufaktur yang terdaftar di Bursa Efek Indonesia. Jurnal Ilmiah Mahasiswa Akuntansi, 1(1), 26-30. 
Yip, E., Van Staden, C., \& Cahan, S. (2011). Corporate social responsibility reporting and earnings management: The role of political costs. Australasian Accounting, Business and Finance Journal, 5(3), 17-34.

Yuliana, R., Purnomosidhi, B., \& Sukoharsono, E. G. (2008). Pengaruh karakteristik perusahaan terhadap pengungkapan corporate social responsibility (CSR) dan dampaknya terhadap reaksi investor. Jurnal Akuntansi dan Keuangan Indonesia, 5(2), 245-276. 